effects of some carcinogens in microbial and mammalian cellular systems.

Dr W. Nichols (Institute of Genetics, Lund) discussed the use of chromosomal aberrations as an indicator for gene mutations. There is a qualitative correlation between the ability of agents to produce chromosome aberrations and gene mutations, but quantitatively the correlation is not good. Furthermore, there is no indication that the mechanism of production of chromosome breaks and mutations is the same. The very great advantage of measuring chromosome aberrations, however, is that it is at present the only available method of detecting effects in man.

One day of the meeting was devoted to a symposium on the effects of caffeine as an environmental mutagen. Dr B. A. Kihlman (Institute of Genetics and Plant Breeding, Uppsala) reviewed many of the known effects of caffeine, describing in particular the work of his own and other groups on the production of chromosome breaks by caffeine in plant and animal cells, and the very powerful potentiating effect of caffeine for cell killing and production of chromosome breaks by other agents (for example, ultraviolet light, alkylating agents).

Dr A. R. Lehmann (University of Sussex) showed that, biochemically, caffeine specifically inhibits the filling in of daughter-strand gaps opposite lesions in damaged DNA, thus linking effects at the molecular level to observations at the chromosomal and cellular level. Dr J. J. Roberts (Chester Beatty Research Institute, Pollards Wood) showed that inhibition of this post-replication repair process could lead to chromosome damage, mutagenesis and cell death. Dr F. H. Sobels (University of Leiden) described work by Dr D. Mendelson and himself, using mutant strains of Drosophila. Caffeine appeared to inhibit a system in female flies which after mating repaired damage produced in the sperm of X-irradiated males. There was general agreement, however, that at the plasma levels produced by consumption of common beverages, caffeine is probably not a hazard, and there certainly was no apparent curtailment of coffee consumption after the symposium.

In the contributed papers mutagenic effects of, for example, various chemicals and pesticides in a wide variety of sys. tems were reported. The test systems ranged from simple microorganisms through host-mediated assays to measurements of dominant lethals, specific locus changes in mice and chromosome aberrations in man. Several groups presented results with eukaryotic microorganisms as the test system, and they suggested that simple experiments with nucleated organisms are likely to be of more relevance to man than are corresponding experiments with prokaryotes.

\title{
SELENOLOGY
}

\section{Stepwise Velocity}

from our Geomagnetism Correspondent

BY any standards, the most important and rewarding lunar "geophysical" data to emerge from the Apollo project must surely be those derived from the various seismological experiments. As a result of pre-Apollo 17 studies, the $P$ wave velocity in the Moon is now known to increase rapidly from $0.1-0.3 \mathrm{~km} \mathrm{~s}^{-1}$ in

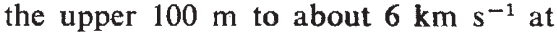
depths of $15-20 \mathrm{~km}$. But because of the lack of seismic travel time data at source-detector distances of less than $30 \mathrm{~km}$, the details of this overall variation have remained obscure and the structure of the upper $10 \mathrm{~km}$ of the Moon is thus poorly defined. In the absence of information to the contrary, some workers have therefore assumed the velocity-depth distribution for $\mathbf{P}$ waves to be smooth. Kovach and Watkins (Moon, in the press), for example, have taken this line, but also suggest that a rate of velocity increase of about $2 \mathrm{~km} \mathrm{~s}^{-1}$ per kilometre could hardly be explained solely by the effect of increasing pressure.

But such is the present rate of progress in lunar research that Kovach and Watkins (Science, 180, 1063; 1973) are now able to report that their own previous beliefs have been overtaken by events. During the Apollo 17 mission a triangular array of four seismometers was successfully installed in the TaurusLittrow region of the Moon and recorded strong seismic signals from eight explosive charges and the crash of the lunar module ascent stage. The charges gave seismic travel time data in the distance range $0.1-2.7 \mathrm{~km}$ only, but the source-detector distance was increased significantly by the impact of the lunar module $8.7 \mathrm{~km}$ away.

The resulting time-distance graph clearly shows that, in the TaurusLittrow area at least, the Moon is layered, for the $\mathrm{P}$ wave velocity increases with depth in a stepwise manner. Because the minimum source-detector distance achieved was about $100 \mathrm{~m}$, the structure of the upper $20 \mathrm{~m}$ or so could not be resolved. Below this thin surface shell, however, the measured seismic velocity is $0.25 \mathrm{~km} \mathrm{~s}^{-1}$ over a depth range of $248 \mathrm{~m}$, rising abruptly to $1.2 \mathrm{~km} \mathrm{~s}^{-1}$ for a further $925 \mathrm{~m}$. The velocity then increases sharply to $4 \mathrm{~km}$ $s^{-1}$, although because of the paucity of data at distances greater than $3 \mathrm{~km}$ from the array (the only point is that from the lunar module impact) there is some uncertainty in this value. But precise values apart, the important point is that material with velocity $\geqslant 4 \mathrm{~km} \mathrm{~s}^{-1}$ underlies the $1.2 \mathrm{~km} \mathrm{~s}^{-1}$ material.

So much for the physical structures of the upper few kilometres of the Moon. But is it also possible to deduce anything about the nature of the seismic

\section{Precumbrian on the Rockall Bank}

IN Nature Physical Science next Monday (July 9), Roberts, Ardus and Dearnley report on material obtained from drilling into two solid outcrops sixty miles apart on the Rockall Bank. At both sites they obtained granulite facies metamorphic rocks and so confirm conclusively what had been deduced from earlier work. At a site on Briony Bank they found an acid granulite containing a relatively small amount of orthopyroxene and even less clinopyroxene. The petrography is similar to that of hypersthene granulite dredged from the vicinity of Rockall Bank. At a second site they found an orthopyroxene-bearing granulite. Both rocks could readily be matched in the Outer Hebrides and north-west Highlands. The whole rock date of $1,670 \pm 24 \mathrm{~m} . \mathrm{y}$. and that on hornblende at $1,566 \pm 33 \mathrm{~m}$.y. indicate a Laxfordian age for the material, although the authors point out that still older Scourian rock may be present.

The demonstration of Roberts et al. that part of Rockall Bank is underlain by such Precambrian rocks is of considerable geological interest. In southern Greenland granulite facies rocks between 1,800 and 1,600 m.y. old are present and in both Greenland and north-west Scotland considerably older granulite facies rocks approximately $3 \times 10^{9}$ yr old are widespread. Furthermore, pebbles in the younger Late Precambrian Torridonian formation of north-west Scotland known to be derived from the west of the British Isles include high grade metamorphic rocks in these two age groups. It would seem that the way is now open for a more precise reconstruction of the Precambrian rocks of north-west Europe, of the microcontinent below the Rockall Bank and of Greenland.

The boundary of the Precambrian Grenville province, as Roberts, Ardus and Dearnley point out, may lie at the southern edge of the Rockall Bank. This province lies to the south of Greenland and has never been recognized in northern Scotland, though rocks of Grenville age occur outside Canada, in southern Norway and the Western Approaches to the English Channel. The new work could lead to the location of this important structure which apparently crosses the British Isles, dividing the basement below Britain into an older north-westerly section of Laxfordian and Scourian and Prescourian age $\left(>1.4 \times 10^{9} \mathrm{yr}\right)$ and a younger southeasterly position formed since $1.2 \times 10^{9}$ yr ago. 